\title{
A NEW SITE OF BURIED PEAT AT LÕPE, SW ESTONIA
}

\author{
Anto RAUKAS, Kai KIMMEL, and Raivo RAJAMAE
}

Eesti Teaduste Akadeemia Geoloogia Instituut (Institute of Geology, Estonian Academy of Sciences), Estonia pst. 7, EE-0100, Tallinn, Eesti (Estonia)

Received 29 August 1994, accepted 20 October 1994

Abstract. Older organic lagoonal, lacustrine, or paludal deposits underlie transgressive marine sediments in more than hali a hundred localities in Estonia enabling the correlation of shorelines and marine sediments. Buried peat in an area of 1 hectare at Lope was analysed palynologically and dated by the ${ }^{14} \mathrm{C}$ method. The Pre-Boreal pollen spectrum and two ${ }^{14} \mathrm{C}$ dates $(9216 \pm 70$ and $9258 \pm 69 \mathrm{yr} \mathrm{BP})$ suggest that in this region the Ancylus transgression reached its maximum about 9000-9200 years ago.

Key words: buried peat, Ancylus transgression, Baltic Sea, palynology, ${ }^{14} \mathrm{C}$ dates, shore lines.

\section{INTRODUCTION}

Estonia is acknowledged as a key area for solving several topical problems concerning the evolution of the Baltic Sea. Among the major problems to be addressed are the beginning and duration of the Ancylus Lake, and in particular, the age of the Ancylus transgression. Due to the different tectonic situation and intensity of vertical movements of the Earth's crust the Ancylus transgression culminated at different times in different Baltic Sea areas (Кессел \& Раукас, 1984). In spite of the rather rapid rise of the water level during the Ancylus transgression its maximum in Finland should be somewhat older than in Estonia. On the other hand, however, big age differences in close-lying sections are sometimes rather difficult to explain. Therefore, every new site of buried organic material will impart valuable information for establishing the exact age of transgression. In the spring of 1991 a very promising site of buried peat was discovered at Lõpe in the village of Kilksamaa, Pärnu County, by Reet Karukäpp. The first author together with Reet Karukäpp and Rein Vaikmäe studied it in August 1991.

\section{THE GEOLOGY OF THE LÖPE SITE}

The site at an absolute height of $9.6 \mathrm{~m}$ on a coastal terrace is situated in the fields of the Lõpe farm (Fig. 1). The bottom of the section is at a height of $7.9 \mathrm{~m}$. The $18-\mathrm{cm}$-thick buried organic layer (Phragmites peat with wood, mainly pine trunks) was found at an absolute height of $8.6-8.78 \mathrm{~m}$. 


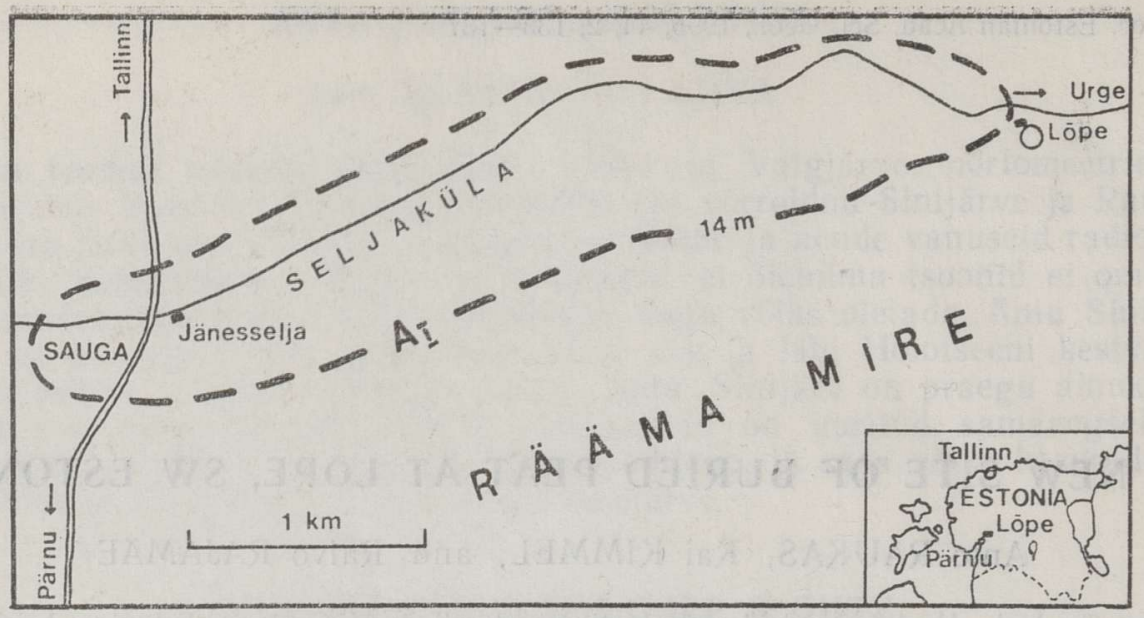

Fig. 1. Location of the Lõpe site.

The lithology of the studied section is as follows:

$0.00-0.20 \mathrm{~m}$ : sandy soil;

$0.20-0.50 \mathrm{~m}$ : gravel;

$0.50-0.60 \mathrm{~m}$ : bluish-grey silt;

$0.60-0.68 \mathrm{~m}$ : pink fine-grained sand;

$0.68-0.71 \mathrm{~m}$ : blackish-grey silt;

$0.71-0.81 \mathrm{~m}$ : pink fine-grained sand;

$0.81-1.00 \mathrm{~m}$ : blackish-grey silt with nests of organic matter;

$1.00-1.18 \mathrm{~m}$ : dark brown thick well-decomposed Phragmites peat with fragments and trunks of wood (mainly pine);

$1.18-1.45 \mathrm{~m}$ : grey loamy carbonaceous (c. $90 \%$ pebbles and gravel grains) till. The upper part of the till is rewashed and more sandy.

The buried organic peat was studied in an area of about 1 hectare in land improvement excavations.

\section{PALYNOLOGY OF THE PEAT LAYER}

The section was analysed palynologically by Kai Kimmel. The samples above the peat layer were taken at every $5 \mathrm{~cm}$, and from the peat at every $2 \mathrm{~cm}$. In the covering sand and silt pollen grains were either entirely absent or only occasional redeposited grains were found. Therefore, it was not possible to draw a reliable pollen diagram.

On the ground of the palynological data Kai Kimmel divided the buried organic layer into two local pollen assemblage zones (PAZ; Fig. 2) both belonging to the Pre-Boreal chronozone. In the Pinus-Betula -Cyperaceae PAZ, Lõ-1, depth 8.66-8.78 m, Pinus ranges from 10 to $40 \%$ and Betula mainly from 15 to $30 \%$ (in one sample $55 \%$ ). Pinus is the dominant. The proportion of Betula nana is up to $2 \%$. The sum of herbaceous plants is relatively high (up to $30 \%$ ). Gramineae make up $20 \%$. Cyperaceae are common. Filipendula reaches $5 \%$. Artemisia, Chenopodiaceae, and Polypodiaceae are rare. The content of Salix is $1-3 \%$. 


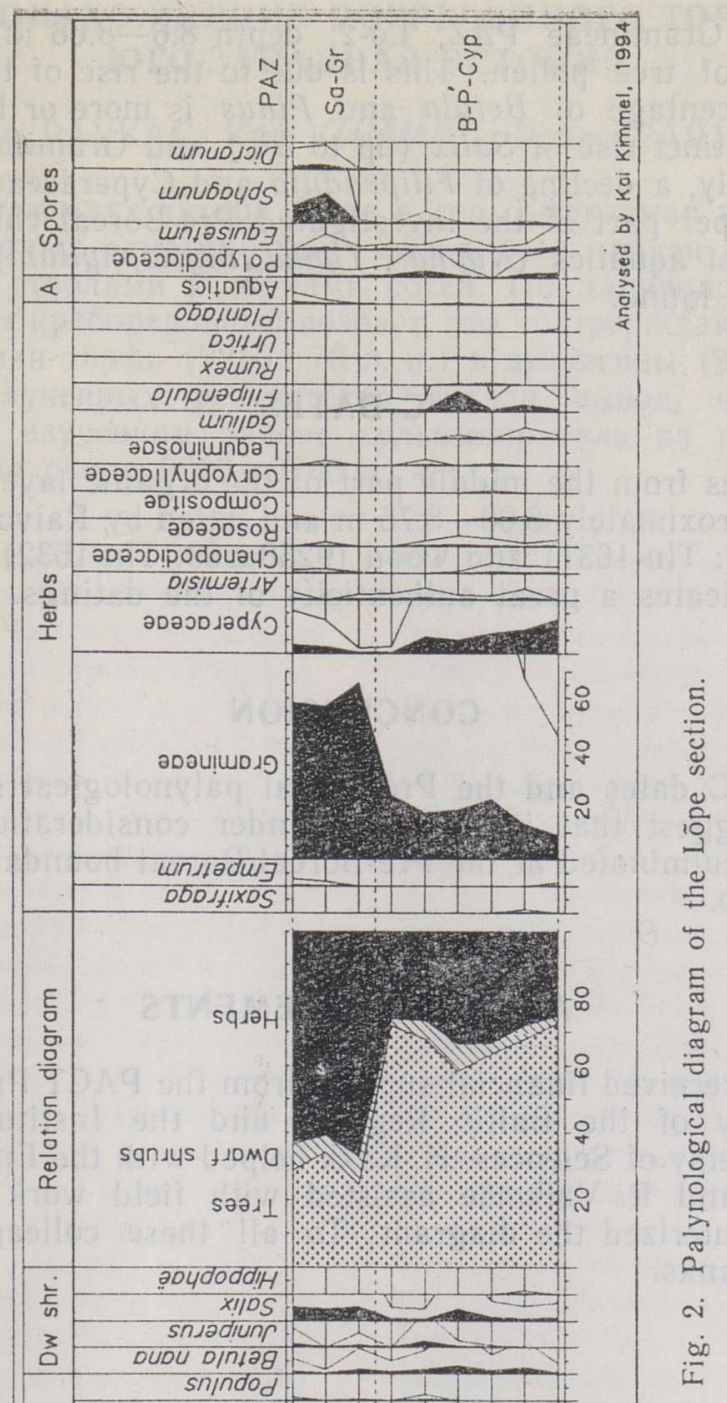


The Salix-Gramineae PAZ, Lõ-2, depth $8.6-8.66 \mathrm{~m}$, differs in the lower values of tree pollen. This is due to the rise of the groundwater level. The percentage of Betula and Pinus is more or less equal (both c. $15 \%$ ). A distinct rise of Salix (up to $5 \%$ ) and Gramineae (up to $6 \%$ ) and, respectively, a decline of Filipendula and Cyperaceae are characteristic of the upper part of the investigated Pre-Boreal chronozone. Some pollen grains of aquatics (Nyphar, Typha, Myriophyllum) and spores of Sphagnum are found.

\title{
${ }^{14}$ C DATES
}

Two samples from the middle part of the organic layer were taken at a depth of approximately $8.68-8.75 \mathrm{~m}$ and dated by Raivo Rajamäe. Both peat $(9216 \pm 70$ : $\operatorname{Tln}-1631)$ and wood $(9258 \pm 69$ : Tln-1632) yielded similar ages. This indicates a great authenticity of the datings.

\section{CONCLUSION}

Both the ${ }^{14} \mathrm{C}$ dates and the Pre-Boreal palynological spectrum of the buried peat suggest that in the area under consideration the Ancylus transgression culminated at the Pre-Boreal/Boreal boundary about 90009200 years ago.

\section{ACKNOWLEDGEMENTS}

This study received financial support from the PACT Project "Environmental History of the Baltic Region" and the Institute of Geology, Estonian Academy of Sciences. H. Kukk helped with the English language. R. Karukäpp and R. Vaikmäe assisted with field work and sampling. S. Veski computerized the diagram. To all these colleagues we proffer our sincere thanks.

\section{REFERENCES}

Кессел Х., Раукас А. 1984. О геологической корреляции древнебереговых образований Балтийского моря в Эстонии и Швеции. - Изв. АН ЭССР. Геол., $33,3 / 4,146-157$.

\section{UUS MATTUNUD TURBA LEIUKOHT LÕPEL EDELA-EESTIS}

\author{
Anto RAUKAS, Kai KIMMEL, Raivo RAJAMAE
}

1991. aastal leiti Kilksamaa külas Pärnumaal Lõpe talu maadel absoluutkõrgusel 8,60-8,78 meetrit puutüvesid ja -oksi sisaldav mattunud turba kiht. Palünoloogilise analüüsi alusel on turvas Preboreaalse vanusega. Seda kinnitas ka turba (9216 \pm 70 a.t.) ja selles leiduva puidu (9258 \pm 69 a.t.) radiosüsiniku analüüs. Saadud tulemuste alusel võib järeldada, et Antsülusjärve transgressioon toimus uuritud alal Preboreaali ja Boreaali piiril ligikaudu 9000-9200 aastat tagasi. 
НОВОЕ МЕСТОНАХОЖДЕНИЕ ПОГРЕБЕННОГО ТОРФА В ЛЫПЕ, ЮГО-ЗАПАДНАЯ ЭСТОНИЯ

Анто РАУКАС, Кай КИММЕЛ, Райво РАЯМЯЭ

В 1991 г. на землях хутора Лыпе в дер. Килксамаа в уезде Пярнумаа на абсолютных отметках $8,60-8,78$ м был найден слой погребенного торфа со стволами и ветками сосен. По палинологическим данным, торф имеет пребореальный возраст, что подтверждают и радиоуглеродные датировки торфа (9216 \pm 70 л. н.) и древесины (9258 \pm 69 л. н.). На основе полученных результатов сделан вывод, что анциловая трансгрессия в изученном районе кульминировала на границе пребореала и бореала около 9000-9200 л. н. 